\title{
Evaluation of Control Method Failures for Exposure to Sandblasting Silica Dust in a Steel Construction Company, Indonesia
}

\section{Aditya Tetra Firdaussyah ${ }^{1}$, Tri Suryo², and Hendra ${ }^{3}$}

${ }^{1,2}$ Candidate of Master in Occupational Health \& Safety, Faculty of Public Health, University of Indonesia

${ }^{3}$ Master in Occupational Health \& Safety, Faculty of Public Health, University of Indonesia

\section{Abstract}

Silica is one of the materials most commonly used for sandblasting in steel construction. Occupational diseases caused by exposure to silica dust occur in several countries, both developed and developing. In order to prevent the occurrence of such diseases, some developed countries have regulated methods to control

Corresponding Author: Aditya Tetra Firdaussyah aditya.tetra@ui.ac.id

Received: 21 January 2018 Accepted: 8 April 2018

Published: 17 May 2018

Publishing services provided by Knowledge

(c) Aditya Tetra Firdaussyah et al. This article is distributed under the terms of the

Commons Attribution License, which permits unrestricted use and redistribution provided that the original author and source are credited.

Selection and Peer-review under the responsibility of the 2nd International Meeting of Public Health 2016 Conference Committee. exposure to silica dust, but in developing countries like Indonesia, methods of controlling exposure to silica dust are not regulated and upper respiratory infection among sandblasting workers still happens. This study aimed to evaluate the failure of implementing methods of controlling exposure to silica dust during sandblasting in a steel construction company in Indonesia. Aspects that were evaluated included control efforts such as the control equipment, ventilation systems, standard operating procedures (SOPs), and the concentration of silica dust in the workplace. The evaluation was conducted by comparing the expected targets of the control efforts with the concentration of silica dust in the workplace. Evaluation results showed that the control methods are sufficient when viewed from the performance of the equipment used. However, in general, the control measures were not effective because high concentrations of silica dust were found in the workplace because implementation of the SOPs was not optimal, and the disparity or variation in the workers understanding of the application of the SOPs. Therefore, the understanding of the procedures and supervision of sandblasting should be increased.

Keywords: sandblasting, silica dust, control method, evaluation of failure

\section{INTRODUCTION}

Utilization of almandine garnet $\left(\mathrm{Fe}_{3} \mathrm{Al}_{2}\right)\left(\mathrm{SiO}_{4}\right)_{3}$ containing crystalline silica as a sandG OPEN ACCESS 
containing silica, which is considered safe within industry best practices and is permitted to be utilized in Indonesia as per the Indonesian environmental board. Records shown at least 1.7 million USA workers are potentially exposed to crystalline silica [13]. It is estimated that in India there are 11.5 million workers exposed to silica dust in both the organized and unorganized labor sectors [10]. In Singapore, there are 1,666 Chinese people at risk from working with granite (Chia 1991). In Indonesia, there is insufficient data of workers exposed to silica dust even though the utilization of silica is abundant. The Occupational Safety and Health Administration (OSHA) has developed specific controls to set appropriate engineering controls, personal protective equipment, and respirators as well as work practices to protect employees from silica dust by workers [5]. In India, control of silica exposure is an ongoing process, whilst in Indonesia control of silica exposure has not yet been specifically developed.

Inadequacy of crystalline silica exposure protection can result in silicosis, and it is reported that from 1990-1996, there were 200-300 deaths per year, known to have occurred where silicosis was identified as a contributing cause on the death certificates [19], whilst in Indonesia, there have been numbers of silicosis cases allegedly from exposure to sandblasting for steel construction. Based on data collected from company's primary health care, the number of people complaining of upper respiratory infection from alleged exposure to silica increased from 2014 to 2016 (PT X, 2016).

Because many Indonesian companies use silica products for sandblasting, especially in steel construction, and since there is no standardized control methods as per government regulation [2], and crystalline silica is classified as a human carcinogen [9], the authors wanted to evaluate control methods for silica-quartz fraction exposure from almandine garnet as a sandblasting agent in steel construction companies that already set and comply with industry best practice in Indonesia. It is hoped that in the near future this evaluation will be a reference for the development of safe working methods for silica utilization in order to efficiently and effectively protect workers.

\subsection{Research Aim}

This study aimed to evaluate the effectiveness of controls to reduce exposure of workers to crystalline silica by comparing the amount of silica exposure to occupational exposure levels (OELS) set by OSHA; Permissible Exposure Limits, American Conference of Governmental Industrial Hygienists (ACGIH) Threshold Limit Values, and Indonesian law regulating OELs as well as risk assessments of silica-quartz exposure. 


\section{METHODS}

The subject of this study was the steel fabrication yard of an engineering, construction, procurement, and installation company that supports oil and gas industries and undertakes sandblasting using the above-mentioned sandblasting agents. The study used a cross-sectional study method to evaluate the controls, focused on processfugitive sources over certain time intervals, and initiated a description and assessment of a sandblasting design control philosophy, dust suppression and ventilation systems, and standard operating procedures for carrying out sandblasting [11]. Evaluation of the controls was determined by the amount of silica (size selective sampling was used to measure the respirable phase) and calculation of the silica-quartz dose exposure to workers as a fraction of the silica [16].

\section{RESULTS}

\subsection{Sandblasting Design Control Philosophy}

Sandblasting produces large amounts of silica dust due to the utilization of pressurized air to blast the sandblasting agent via a blasting pot. To prevent dust-pollution in the workplace, sandblasting is done in a fully enclosed area fabricated from metal with an access way, the so-called sandblasting room [5]. There were two identical sandblasting rooms, fully designed and designated areas, to carry out sandblasting. No massive sandblasting activity was allowed or permitted unless it was in this designated area, and only a limited number of workers were permitted to take part in this activity. Through this safety philosophy, exposure of non-related workers to silica and quartzsilica will be reduced, so the risk of exposure will be low [5].

\subsection{Dust Suppression and Ventilation Systems}

Local exhaust ventilation was utilized to support the sandblasting room operation consisting of hoods, ducting, fans, and air cleaners [12]. Flanged multiple-slot opening hoods (200 mm wide by $500 \mathrm{~mm}$ high) directed at the sandblasting were located around 1,200 $\mathrm{mm}$ above ground, and airflow was suctioned through fixed galvanized ducting connected to the hood particulate filters, commonly called a baghouse, to collect the silica, which is regularly cleaned and maintained. The suction system that draws off the contaminated air used radial blade fans with air flow rates of 25,000 


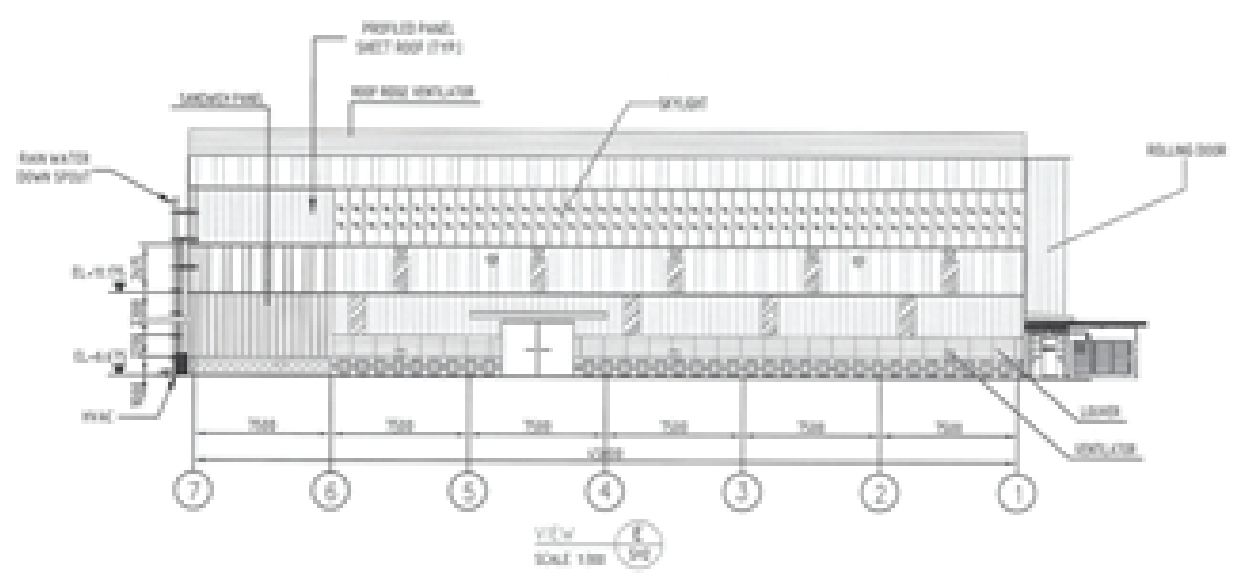

Figure 1: Sandblasting room design.

$\mathrm{m}^{3} / \mathrm{h}$, with the fans total head ca. $240 \mathrm{~mm}$. Compressed air was required, $0.4 \mathrm{~m}^{3} / \mathrm{min}$, and it was assumed that the make-up of the air was more than 10\% of the exhaust rate and there was no pressure loss in the ducts. Based on the calculation of airflow principles provided by design engineering compared to silica exposure, which has a heavier mass than air, it was found that the exhaust system capacity was adequate [18].

\subsection{Sandblasting Standard Operation Procedure}

Protection of workers from sandblasting focusing on occupational health and safety was clearly mentioned on the sandblasting safe work practice procedure. The procedure included a safety measure standard, administrative requirements such as a prejob start meeting, a toolbox talk, and the requirement that employees must attend health and safety promotions specific to sandblasting prior to commencing the activity via a classroom training session [5]. In order to implement occupational health in this activity, it was mentioned that sandblasting workers would be equipped with respiratory protection equipment (RPE) with specific characteristic. The RPE supplied respirator air sourced from an air compressor through a flexible hose containing a CPF air filter with a High Efficiency Particulate (HEPA)100 class filter [3]. The volume of compressed air for breathing was $20 \mathrm{cfm}$ at 90-100 psi when using a Cool Air Tube. The OSHA assigned protection factor for this respiratory protection system is 1000 Based on the OEL of almandine garnet, this helmet could hold $4000 \mathrm{mg} / \mathrm{m} 3$ silica dust exposure.

Disparity was observed when sandblasting commenced and the sampling was in progress. Safe working required that when the sandblasting room was in operation 


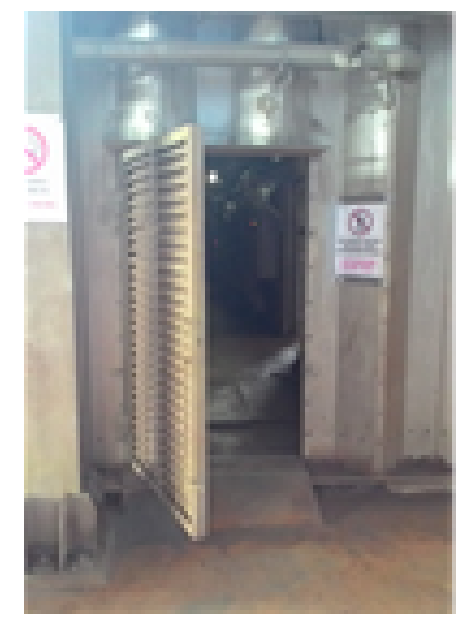

Figure 2: Disparity in standard operating procedure - access door open when sandblasting was taking place and lack of a self-closing non-gasketed door.

all opening should be closed to enable the ventilation system to work effectively, but this was not done and silica dust was released into the surrounding environment [5]. Another disparity was also observed in the construction of the sandblasting-room door, which should have been a self-closing gasketed door [5].

\subsection{Determination of Control Effectiveness}

\subsubsection{Measurement of Respirable Size Silica Exposure}

Exposure data sampling collection was done by a third-party government owned laboratory accredited by the Indonesian Committee of Accreditation ("Komite Akreditasi Nasional" - KAN) complying with ISO 17025 for laboratory management systems. Sampling was done around the second quarter of 2015 between June 10and June 11, 2015 during dayshift sandblasting using sampling method NIOSH 7500 for collecting silica dust in ambient аir [4]. There were eight sampling points located around the sandblasting room. The measurements showed that silica exposures were greatly above the OEL at all sampling points, and it is suggested that this happened because of the disparities described in the previous assessment section.

\subsection{Calculation of Silica-Quartz Dose Exposure to Workers}

Instead of measuring silica dust to evaluate the controls, evaluation to measure the quartz fraction of the silica exposure, when silica is being utilized as a sandblasting 
TABLE 1: Silica sampling measurements compared to OEL.

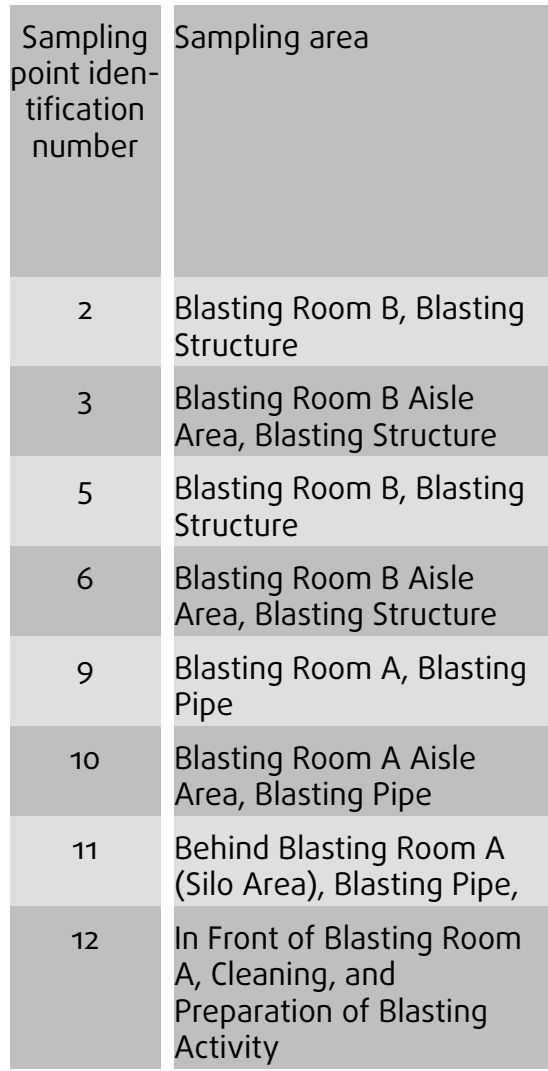

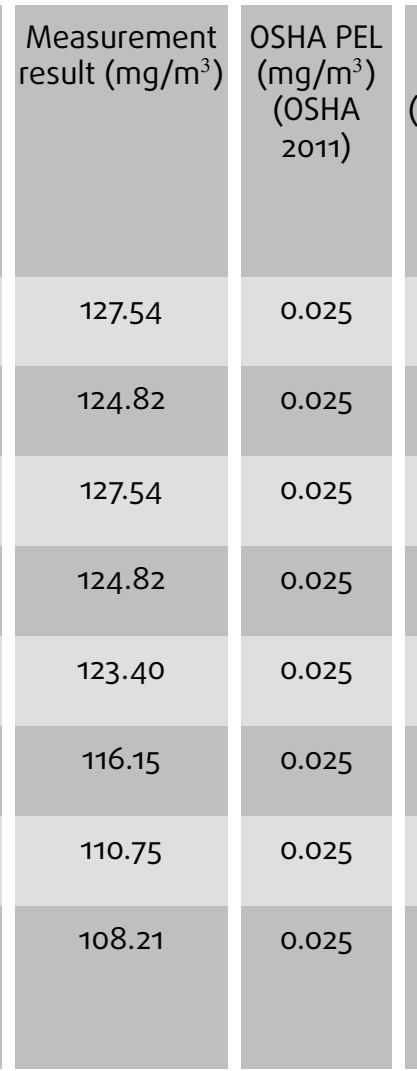

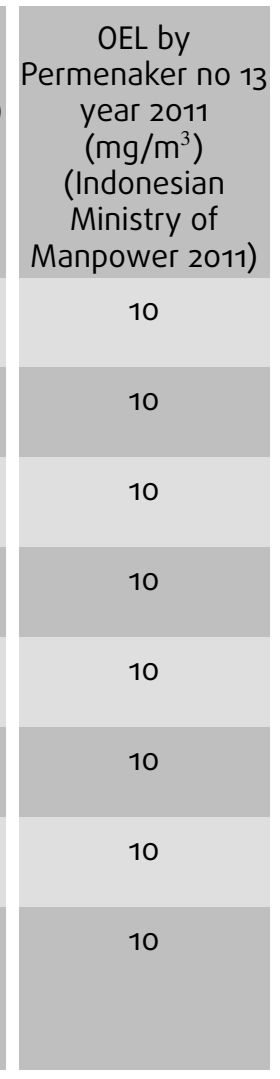

agent, by calculating a lifetime average daily dose (LADD), a risk for carcinogen (RfD), and a lifetime risk for carcinogens were calculated using some equations [7].

$$
\begin{gathered}
A D D=\frac{C_{\text {sampling point } 2} \cdot c \cdot I R \cdot R F \cdot E L \cdot A F \cdot E D \cdot 10^{-6}}{B W \cdot T L} \\
R f D=\frac{M D D}{A D I} \\
\text { Risk }=L A D D \cdot S F
\end{gathered}
$$

Exposure evaluation was assumed by using several presumptions and assumptions based on field observations and literature references as applicable. It was assumed that no respiratory protection equipment was used, but dermal protection was fully in place to protect the whole body, so it was assumed that there was no dermal exposure when the sandblasting took place. It was presumed that over eight hours of work time, workers were exposed to the respirable form of silica quartz for around seven hours, for around 300 days per year. Workers were typically adult males aged 25-years-old with an average body weight of $70 \mathrm{~kg}$ with an assumed typical lifetime of around 30 years. Based on the referenced literature, sandblasting is categorized as a heavy activity and a typical adult male inhalation rate for heavy activity is $4.8 \mathrm{~m}^{3} /$ hour [14]. 
The respirable fraction of the silica was assumed to be $100 \%$ using an aerodynamic diameter of around $3 \mu \mathrm{m}$ and the concentration of quartz in the almandine garnet was set at $0.5 \% \mathrm{w} / \mathrm{w}$ or $5,000 \mathrm{mg} / \mathrm{kg}$.

Because the subject of the current research is the toxicity of quartz, the human dose response was interpolated from the dose response effect of silica quartz to animals [7] using a human equivalent dose equation. The human dose of an agent is expected to induce the same severity of the toxic effect that an animal dose induced. The value of the Human Equivalent Dose (HED) is the extrapolation to humans of silica exposure concentration to rats, which in the laboratory experiment was five hours per day; four days a week for one year to determine the retardation clearance rate or time from the respiratory region of the lungs. Thus, a lower clearance rate or time will cause deposits of silica in the respiratory region that lead to persistent inflammation neutrophils, which creates oxidants than can cause tumors in the respiratory region if the exposure is latent; decrease lung volume; decrease respiratory system compliance; decrease the N2 slope; decrease diffusion capacity for carbon monoxide; and decrease flow expiratory force [14].

$$
\begin{aligned}
& H E D=\text { rat exposure concentration to silica } \cdot\left(\frac{\text { human body weight }}{\text { rat body weight }}\right)^{\frac{1}{3}} \\
& \qquad \begin{aligned}
H E D & =21.1 \frac{\mathrm{mg}}{\mathrm{m} 3} \cdot\left(\frac{70}{0.25}\right)^{\frac{1}{3}} \\
H E D & =21.1 \frac{\mathrm{mg}}{\mathrm{m} 3} \cdot 6.5421 \\
H E D & =138.0389 \mathrm{mg} / \mathrm{m} 3
\end{aligned}
\end{aligned}
$$

This means that if silica exposure to a worker via inhalation exceeds $138.034 \mathrm{mg} / \mathrm{m}^{3}$ for such time, adverse health effects as mentioned may occur. Instead of calculating the HED, the acceptable daily intake was also calculated to determine the safe exposure level per day of quartz silica in the workplace.

The sampling results from the eight sampling points showed variation in the data based on the characteristics of the location and exposure criteria. However, the focus of the current research was quartz silica found as $0.5 \% \mathrm{w} / \mathrm{w}$ in almandine garnet. Thus, the level of quartz exposure was calculated from the lifetime average daily dose using the presumptions mentioned previously.

Calculations of lifetime average daily doses from the several sampling points were directly proportional with the measured silica from the sandblasting. Quartz LADD 
calculations showed that the lifetime average daily dose from sandblasting, based on the presumptions above, were still below the HED until it became symptomps on human body. Furthermore, the risks for carcinogens were mostly insignificant for those amounts of exposure as the Lifetime Average Daily Dose (LADD) were mostly below the HED. Whilst the risk for lifetime cancer from quartz exposure by this amount of almandine garnet usage were insignificant, the severity factor (SF) of quartz inhalation was determined as 10-6 (risk is insignificant) [7].

TABLE 2: Calculated toxicity risk assessment of quartz silica from sandblasting.

\begin{tabular}{c|l}
$\begin{array}{c}\text { Sampling } \\
\text { point } \\
\text { identification } \\
\text { number }\end{array}$ & Sampling area \\
\hline 2 & $\begin{array}{l}\text { Sandblasting Room B, Blasting } \\
\text { Structure }\end{array}$ \\
\hline 3 & $\begin{array}{l}\text { Sandblasting Room B Aisle Area, } \\
\text { Blasting Structure }\end{array}$ \\
\hline 5 & $\begin{array}{l}\text { Sandblasting Room B, Blasting } \\
\text { Structure }\end{array}$ \\
\hline 6 & $\begin{array}{l}\text { Sandblasting Room B Aisle Area, } \\
\text { Blasting Structure } \\
\text { Sandblasting Room A, Blasting Pipe }\end{array}$ \\
\hline 9 & $\begin{array}{l}\text { Sandblasting Room A Aisle Area, } \\
\text { Blasting Pipe } \\
\text { Behind Sandblasting Room A (Silo } \\
\text { Area), Blasting Pipe, }\end{array}$ \\
\hline 11 & $\begin{array}{l}\text { In Front of Sandblasting Room A, } \\
\text { Cleaning, and Preparation of } \\
\text { Blasting Activity }\end{array}$ \\
\hline 12 & \begin{tabular}{l} 
Saling \\
\hline
\end{tabular}
\end{tabular}

\begin{tabular}{|c|c|c|}
\hline $\begin{array}{c}\text { LADD from } \\
\text { Inhalation of } \\
\text { Quartz in Air } \\
\text { (mg/kg body } \\
\text { weight/day) }\end{array}$ & $\begin{array}{c}\text { RfD Risk for } \\
\text { Carcinogen }\end{array}$ & $\begin{array}{c}\text { Risk for } \\
\text { lifetime } \\
\text { cancer }\end{array}$ \\
\hline 0.3 & 0.075 & $0.3 \cdot 10^{-6}$ \\
\hline 0.299 & 0.0748 & $2.99 \cdot 10^{-7}$ \\
\hline 0.3 & 0.075 & $0.3 \cdot 10^{-6}$ \\
\hline 0.299 & 0.0748 & $2.99 \cdot 10^{-7}$ \\
\hline 0.296 & 0.074 & $2.96 \cdot 10^{-7}$ \\
\hline 0.278 & 0.0695 & $2.78 \cdot 10^{-7}$ \\
\hline 0.2658 & 0.06645 & $2.658 \cdot 10^{-7}$ \\
\hline 0.259 & 0.06475 & $0.259 \cdot 10^{-6}$ \\
\hline
\end{tabular}

\section{CONCLUSIONS}

The authors concluded that the control methods for using almandine garnet $\left(\mathrm{Fe}_{3} \mathrm{Al}_{2}\right)$ $\left(\mathrm{SiO}_{4}\right)_{3}$ for sandblasting in steel construction were adequate but ineffective because of disparities observed in the standard operating procedure that resulted in a high level of exposure. It was concluded that sandblasting should be done in a fully closed system to prevent high exposures outside the sandblasting room.

\section{ACKNOWLEDGEMENTS}

The authors would like to thank to the Indonesian Endowment Fund as sponsor and supporter of this research. 


\section{References}

[1] American Conference of Governmental Industrial Hygienists (ACGIH), 2016. TLVs \& BEls Based on the Documentation of the Threshold Limit Values for Chemical Substances and Physical Agents and Biological Exposure Indices. (Cincinnati, $\mathrm{OH}$ : ACGIH).

[2] Batam Government, 2011. Circular of BatamMayor: Prohibition of Silica Sand as Sandblasting Agent, retrieved from http: //skpd . batamkota.go.id/dampaklingkungan/2011/11/ larangan-penggunaan-pasir-silica-sebagai-material-sandblasting/

[3] Center for Disease Control (CDC), 1987. NIOSH Guide to Industrial Respiratory Protection. Cincinnati, Ohio:NIOSH Publication no 87-116.

[4] Center for Disease Control (CDC), 2003. NIOSH Manual Analytical Method SILICA, CRYSTALLINE, by XRD: METHOD 7500. Retrieved from https://www.cdc.gov/niosh/ docs/2003-154/pdfs/7500.pdf

[5] Center for Disease Control (CDC), 1976. Abrasive Blasting Operations: Engineering Control and Work Practices Manual (Cincinnati, $\mathrm{OH}$ : National Institute for Occupational Safety and Health. NIOSH Publication No. 76-179). Ohio: Cincinnati.

[6] Chia, S. 1991. "Silicosis and lung cancer among Chinese granite workers." Scand J Work Environ Health,117:170-4.

[7] Derelanko, M. J. 2002. Risk Assessment. In Handbook of Toxicology, edited by M. J Derelanko, and M. A. Hollinger, 1000-1199. Boca Raton, FL: CRC Press.

[8] Indonesian Ministry of Manpower, 2011. Threshold Limit Value for Physical and Chemical Factor. Indonesia. Jakarta : PERMENAKER NO 13, 2011.

[9] International Agency for Research on Cancer [IARC], (1997). IARC Monographs on the Evaluation of Carcinogenic Risks to Humans: Silica, Some Silicates, Coal Dust and Para-aramid Fibrils., Vol. 68. (Lyon, France: World Health Organization, International Agency for Research on Cancer).

[10] Jindal, S. 2013. "Silicosis in India: past and present."CurrOpinPulm Med, 119:163-168.

[11] Kouimtzis, T. 2002. "Particulate Emission Control." In Airborne Particulate Matter,editedby T. Kouimtzis, and C. Samara, 279-330. Berlin Heidelberg: SpringerVerlag Berlin Heidelberg.

[12] McDermott, H. J. 2002. "Local Exhaust Ventilation." In Handbook of Toxicology, edited by B. A Plog, and P. J. Quinland, 607-630. Boca Raton: NSC Press.

[13] National Institute for Occupational Safety and Health(NIOSH), 1991. Work-related lung disease surveillance report. (Cincinnati, OH: U.S. Department of Health and 
Human Services, Public Health Service, Centers for Disease Control, Publication No. 91-113, Table 23, p. 38.

[14] Newton, P.E. 2002. Fundamental Inhalation Toxicology. In Handbook of Toxicology, edited by M. J Derelanko, and M. A. Hollinger, 283-346. Boca Raton, FL: CRC Press.

[15] Occupational Safety and Health Administration(OSHA), 1997. Additional Enforcement Policy Change for Respiratory Protection Required for Abrasive Blasting Under the Interim Final Rule for Lead in Construction, 29 CFR1926.62. Retrieved from https://www.osha.gov/pls/oshaweb/owadisp.show_document?p_ table=INTERPRETATIONS\&__id $=22376$

[16] Occupational Safety and Health Administration (OSHA), 2011. Directive \#: CPL 0300-007 National Emphasis Program - Crystalline Silica. Retrieved from https : //www . osha.gov/OshDoc/Directive_pdf/CPL_03-00-007.pdf

[17] Occupational Safety and Health Administration (OSHA), 2011. FR \#: 81:6027260274 Occupational Exposure to Respirable Crystalline Silica; Correction. FR \#: 81:60272-60274. Retrieved from https://www.osha.gov/pls/oshaweb/owadisp. show_document?p_table=FEDERAL_REGISTER\&p_id=27464

[18] Wabeke, R.L. 2013. Air contaminants, ventilation, and industrial hygiene economics: the practitioner's toolbox and desktop handbook. FL, USA: Taylor \& Francis.

[19] Yassin, A. 2005. "Occupational Exposure to Crystalline Silica Dust in the United States, 1988-2003." Environmental Health Perspectives113:3: 255-260. 